\title{
Pengaruh Kualitas Layanan Terhadap Kepuasan dan Loyalitas Nasabah Pada PT Bank Negara Indonesia (Persero) Tbk Unit Siwa Kabupaten Wajo
}

\author{
Muh. Syaiful Islam¹, Nasir Hamzah², Amir Mahmud ${ }^{3}$ \\ ${ }^{1,2,3}$ Magister Manajemen, Universitas Muslim Indonesia. \\ ${ }^{1}$ Koresponden Penulis, E-mail: muhipul27@gmail.com
}

\begin{abstract}
ABSTRAK
Tujuan penelitian ini adalah untuk menganalisis pengaruh kualitas layanan melalui (Tangible, Reliability, Responsiveness, assurance, Emphaty) terhadap kepuasan nasabah. Untuk menganalisis pengaruh layanan melalui Tangible, Reliability, Responsiveness, assurance, Emphaty) terhadap loyalitas nasabah. Untuk menganalisis pengaruh kepuasan nasabah terhadap loyalitas. Untuk menganalisis kualitas layanan (Tangible, Reliability, Responsiveness, assurance, Emphaty) melalui kepuasan nasabah pada PT Bank Negara Indonesia (Persero), Tbk Unit Siwa Kabupaten Wajo. Untuk mengimplemasikan tujuan tersebut maka digunakan analisis deskriptif, uji validitas dan uji reliabilitas, uji asumsi klasik, analisis jalur. Hasil penelitian menemukan bahwa kualitas layanan melalui bukti fisik, kehandalan, daya tanggap, jaminan dan empati berpengaruh postif dan signifikan terhadap kepuasan nasabah. Kualitas layanan melalui bukti fisik, kehandalan, daya tanggap, jaminan dan empati berpengaruh positif dan signifikan terhadap loyalitas nasabah. Hasil uji mediasi yang menunjukkan bahwa kepuasan nasabah tidak dapat memediasi pengaruh kualitas pelayanan melalui bukti fisik, kehandalan, daya tanggap, jaminan dan empati terhadap loyalitas nasabah pada PT Bank Negara Indonesia (Persero), Tbk Unit Siwa Kabupaten Wajo.
\end{abstract}

Kata Kunci: Kualitas; Layanan; Kepuasan; Loyalitas; Nasabah

\begin{abstract}
The purpose of this study is to analyze the effect of service quality through (Tangible, Reliability, Responsiveness, Assurance, Emphaty) on customer satisfaction. To analyze the influence of services through Tangible, Reliability, Responsiveness, assurance, Emphaty) on customer loyalty. To analyze the effect of customer satisfaction on loyalty. To analyze service quality (Tangible, Reliability, Responsiveness, assurance, Emphaty) through customer satisfaction at PT Bank Negara Indonesia (Persero), Tbk. Siwa Unit in Wajo Regency. To implement these objectives, descriptive analysis, validity test and reliability test, classic assumption test, path analysis are used. The results of the study found that service quality through physical evidence, reliability, responsiveness, assurance and empathy had a positive and significant effect on customer satisfaction. Quality of service through tangible, reliability, responsiveness, assurance and empathy has a positive and significant effect on customer loyalty. The mediation test results show that customer satisfaction cannot mediate the effect of service quality through tangible, reliability, responsiveness, assurance and empathy for customer loyalty at PT Bank Negara Indonesia (Persero), Tbk. Siwa Unit in Wajo Regency.
\end{abstract}

Keywords: Quality; Service; Satisfaction; Loyalty; Customer 
Pengaruh Kualitas Layanan, ... (Islam, Hamzah, \& Mahmud) | 164

\section{PENDAHULUAN}

Perkembangan teknologi informasi menjadikan persaingan bisnis dalam lingkungan global semakin kompetitif dan semakin sulit. Banyaknya bermunculan pesaing baru dalam industri yang sama, menjadi ancaman bagi perusahaan yang sedang menjalankan bisnisnya, salah satunya adalah bisnis perbankan. Dunia perbankan merupakan salah satu bidang yang harus tetap mempertahankan eksistensinya sebagai lembaga keuangan dalam perekonomian. Bank sebagai lembaga keuangan Indonesia merupakan intermediasi terbesar dalam sistem financial, menciptakan uang, dan sangat penting dalam menentukan aktifitas perekonomian.

Perkembangan situasi dan kondisi bisnis industri perbankan pada masa mendatang akan semakin kompetitif. Hal ini merupakan proses pendewasaan dari perbankan Indonesia ke arah profesionalisme karena dilaksanakan melalui penciptaan iklim bersaing yang wajar antar bank - bank pemerintah, swasta nasional, maupun bank asing. Oleh karena itu dunia perbankan dituntut untuk menunjukkan kinerja yang semakin baik sehinggah dapat menciptakan sinergi dan memberikan nilai yang tinggi kepada nasabah.

Bank yang bisa menciptakan nilai yang tinggi bagi nasabahnya akan dapat mengakibatkan loyalitas nasabah pada bank tersebut dan merupakan kunci utama bank untuk dapat bersaing dengan bank yang lain. Bank perlu menjaga hubungan jangka panjang dengan nasabah untuk menciptakan loyalitas nasabah terhadap bank.

Menurut (Assauri, 2018) bahwa loyalitas nasabah atau pelanggan adalah merupakan suatu impian dari pemasar, dan sering pula merupakan kunci dari keberhasilan bisnis pemasaran dalam jangka panjang. Konsumen atau nasabah yang loyal merupakan asset yang paling penting dan berharga bagi perusahaan. Untuk menciptakan loyalitas nasabah maka salah satu faktor yang perlu diperhatikan perusahaan dan sangat dominan dari loyalitas nasabah adalah nasabah-nasabah yang puas. Kepuasan nasabah menurut (Herlambang, 2014) adalah tingkat perasaan seseorang setelah membandingkan kinerja (atau hasil) yang dirasakan dibandingkan dengan harapannya. Jadi tingkat kepuasan adalah fungsi dari perbedaan antara kinerja yang dirasakan dengan harapan seseorang terhadap atau jasa yang ditawarkan. Loyalitas nasabah berkaitan dengan kepuasan nasabah, karena loyalitas akan tercipta jika nasabah merasa puas berhubungan dengan bank tersebut, tingkat kepuasan nasabah adalah perbandingan antara nilai jasa yang diterima dengan apa yang diperkirakan akan diterima nasabah tersebut (Kotler, 2016).

Penelitian (Wijayanto, 2015) menemukan bahwa variabel kepuasan pelanggan mempengaruhi loyalitas pelanggan. Kemudian penelitian yang dilakukan (Sigit dan Soliha, 2017) bahwa kepuasan berpengaruh terhadap loyalitas nasabah. Untuk membentuk kepuasan dan loalitas nasabah, maka perbankan yang merupakan industri jasa harus memperhatikan kualitas layanan. Kualitas layanan mempengaruhi kepuasan nasabah, hal ini sesuai dengan teori (Dimyati, 2018) bahwa kualitas pelayanan adalah kualitas sebagai totalitas dari karakteristik dari suatu produk atau jasa yang berhubungan dengan kemampuan untuk memuaskan yang dinyatakan atau tersirat. Kualitas layanan adalah suatu keadaan dinamis yang 
berkaitan erat dengan produk, jasa, sumber daya manusia, serta proses dan lingkungan yang setidaknya dapat memenuhi atau malah dapat melebihi kualitas pelayanan yang diharapkan, dimana terdiri dari tangible (bukti fisik), reliability (kehandalan), assurance (jaminan), responsiveness (daya tanggap) dan emphaty (perhatian). (Tjiptono, 2014).

Kualitas layanan merupakan suatu bentuk penilaian nasabah terhadap tingkat pelayanan yang diterima (perceived service) dengan tingkat layanan yang diharapkan (expected service). Apabila pelayanan yang diterima atau yang dirasakan sesuai yang diharapkan, maka dapat memberikan kepuasan yang tinggi bagi nasabah.

Penelitian ini sejalan dengan yang dilakukan oleh (Dewi, et.al, 2014) hasil penelitian menemukan bahwa kualitas pelayanan berpengaruh positif dan signifikan terhadap kepuasan nasabah pada PT. BPR Hokidi Kabupaten Tabanan. Begitu pula dengan penelitian yang dilakukan oleh (Wijayanto, 2015) dimana hasil penelitian menemukan bahwa kualitas layanan yang terdiri dari tangible, reliability, responsiveness, assurance dan emphaty berpengaruh terhadap kepuasan nasabah bank.

Selain kualitas layanan memberikan pengaruh terhadap kepuasan nasabah, juga dapat memberikan pengaruh terhadap loyalitas nasabah. Hal ini sesuai dengan teori yang dikemukakan oleh (Tjiptono dan Chandra, 2016) konsep kualitas layanan erat kaitannya dengan konsep orientasi pasar (market orientation). Orientasi pasar merupakan serangkaian proses dan aktivitas lintas fungsional yang diarahkan pada upaya penciptaan dan pemuasan pelanggan melalui penilaian kebutuhan secara berkesinambungan. Hal ini menunjukkan bahwa tujuan pelayanan adalah tidak lain mengarah pada kepuasan pelanggan jangka panjang yang mendatangkan loyalitas pelanggan terhadap perusahaan.

Loyalitas dapat dicapai dengan meningkatkan kualitas layanan yang diberikan kepada konsumen dapat juga dengan adanya nilai positif yang tercipta di mata public selama ini terhadap produk ataupun jasa yang ditawarkan di pasaran. Sehingga nantinya diharapkan nasabah akan merasa puas dan dengan sendirinya loyalitas dapat tercipta dalam benak konsumen. Nasabah yang merasa puas terhadap kualitas layanan akan mentransformasikan perasaannya tersebut terhadap loyalitas yang ditunjukkan dengan pembelian kembali secara konsisten dan menyarankan kepada orang lain untuk membeli produk dan layanan dari Bank tersebut. Penelitian (Yaqin dan Ilfitriah. 2014) bahwa terdapat pengaruh yang positif dan signifikan antara variabel kualitas pelayanan terhadap loyalitas nasabah. Kemudian penelitian yang dilakukan (Nardiman, 2014) menemukan bahwa ada pengaruh positif dan signifikan kualitas layanan terhadap loyalitas pelanggan.

Terkait dengan pentingnya masalah kualitas layanan, maka penelitian ini dilakukan pada PT. Bank Negara Indonesia (Persero), Tbk Unit Siwa Kabupaten Wajo. Sebagai perusahaan yang bergerak di bidang jasa perbankan maka untuk mengantisipasi persaingan yang semakin kompetitif dan ketat serta untuk meningkakan jumlah nasabah, maka PT. Bank Negara Indonesia (Persero), Tbk Unit Siwa Kabupaten Wajo perlu meningkatkan kualitas pelayanan, guna memberikan kepuasan bagi nasabah serta mempertahankan nasabah agar tetap loyal atau setia terhadap bank tersebut. Permasalahan yang sering terjadi pada PT. Bank Negara Indonesia (Persero), Tbk Unit Siwa Kabupaten Wajo bahwa nasabah kurang loyal terhadap produk atau jasa 
yang diberikan sehingga menyebabkan terjadi penurunan jumlah nasabah, hal ini disebabkan karena nasabah kurang puas terhadap pelayanan yang diberikan dimana dapat dilihat dari banyaknya antrian yang menunggu sebelum jam 08.00, pelayanan yang berbelit-belit serta adanya diskriminatif bagi nasabah penabung, serta jaringan yang sering kali offline, sehingga pelayanan sangat lambat dan hal ini mempengaruhi kepuasan bagi nasabah dan berdampak kurangnya loyalitas atau kesetiaan nasabah untuk menabung pada PT. Bank Negara Indonesia (Persero), Tbk Unit Siwa Kabupaten Wajo. Berdasarkan pengamatan yang dilakukan bahwa walaupun nasabah berkali-kali datang tidak menjamin nasabah tersebut loyal, tetapi karena terpaksa untuk tetap menggunakan jasa PT Bank Negara Indonesia (Persero), Tbk Unit Siwa Kabupaten Wajo.

Oleh karena itu dengan adanya permasalahan yang terjadi maka perlunya diperhatikan loyalitas nasabah, karena nasabah yang loyal akan selalu menggunakan jasa PT Bank Negara Indonesia (Persero), Tbk Unit Siwa Kabupaten Wajo di kemudian hari dan tidak berniat untuk pindah ke bank lain, serta dengan adanya loyalitas maka nasabah akan merekomendasikan kepada teman, keluarga dan kerabat lainnya mengenai kenggulan-keunggulan yang dimiliki oleh PT Bank Negara Indonesia (Persero), Tbk Unit Siwa Kabupaten Wajo. Untuk meningkatkan loyalitas nasabah maka perlu diterapkan kualitas pelayanan kepada nasabah yang terdiri dari bukti fisik dimana berkaitan dengan penampilan karyawan, kebersihan ruang kantor serta gedung, kehandalan berkaitan dengan kecepatan karyawan dalam melayani nasabah, daya tanggap berkaitan dengan kemampuan karyawan dalam memberikan informasi terkait dengan perbankan, jaminan berkaitan dengan karyawan menumbuhkan rasa kepercayaan kepada nasabah terhadap setiap dana yang disimpan serta empati berkaitan dengan sifat keramahtamahan karyawan dalam melayani setiap nasabah yang datang.

Hal inilah yang menjadi latar belakang pemikiran mengapa tema ini menarik untuk diteliti. dipilihnya bank BNI sebagai objek penelitian, oleh karena sebagai salah satu lembaga keuangan milik pemerintah, Bank BNI saat ini tengah menghadapi era persaingan yang sangat kompetitif. Persaingan bukan hanya dengan sesama bank milik pemerintah, tetapi juga dengan bank-bank swasta serta lembaga-lembaga keuangan non bank lainnya yang rata-rata memiliki produk yang hampir sama. Kondisi semacam ini mau tidak mau mengharuskan setiap bisnis bank yang ada di Indonesia harus dapat mengoptimalkan layanan atau service yang unggul kepada nasabahnya. Tidak terkecuali dengan Bank BNI unit Siwa Kabupaten Wajo. Kemampuan Bank BNI untuk dapat memberikan layanan yang maksimal dari produk-produk yangdi beli dan atau digunakan oleh nasabah, serta kemampuan untuk beradaptasi terhadap perubahan dan kemajuan lingkungan, sosial-budaya serta teknologi, dan perilaku nasabahnya menjadi hal yang sangat penting saat ini.

Kelima kualitas layanan ini perlu diterapkan oleh PT Bank Negara Indonesia (Persero), Tbk Unit Siwa Kabupaten Wajo, karena kualitas pelayanan yang baik diharapkan nasabah akan merasa puas dan dengan sendirinya loyalitas nasabah dapat tercipta dalam benak nasabah, karena keberhasilan Bank Negara Indonesia terletak pada banyaknya nasabah yang menggunakan jasa pada perusahaan tersebut 
melalui loyalitas nasabah untuk tetap menabung pada PT Bank Negara Indonesia (Persero), Tbk Unit Siwa Kabupaten Wajo

Berdasarkan uraian tersebut, maka kerangka konseptual penelitian ini adalah:

\section{Gambar 1. Kerangka Konseptual}

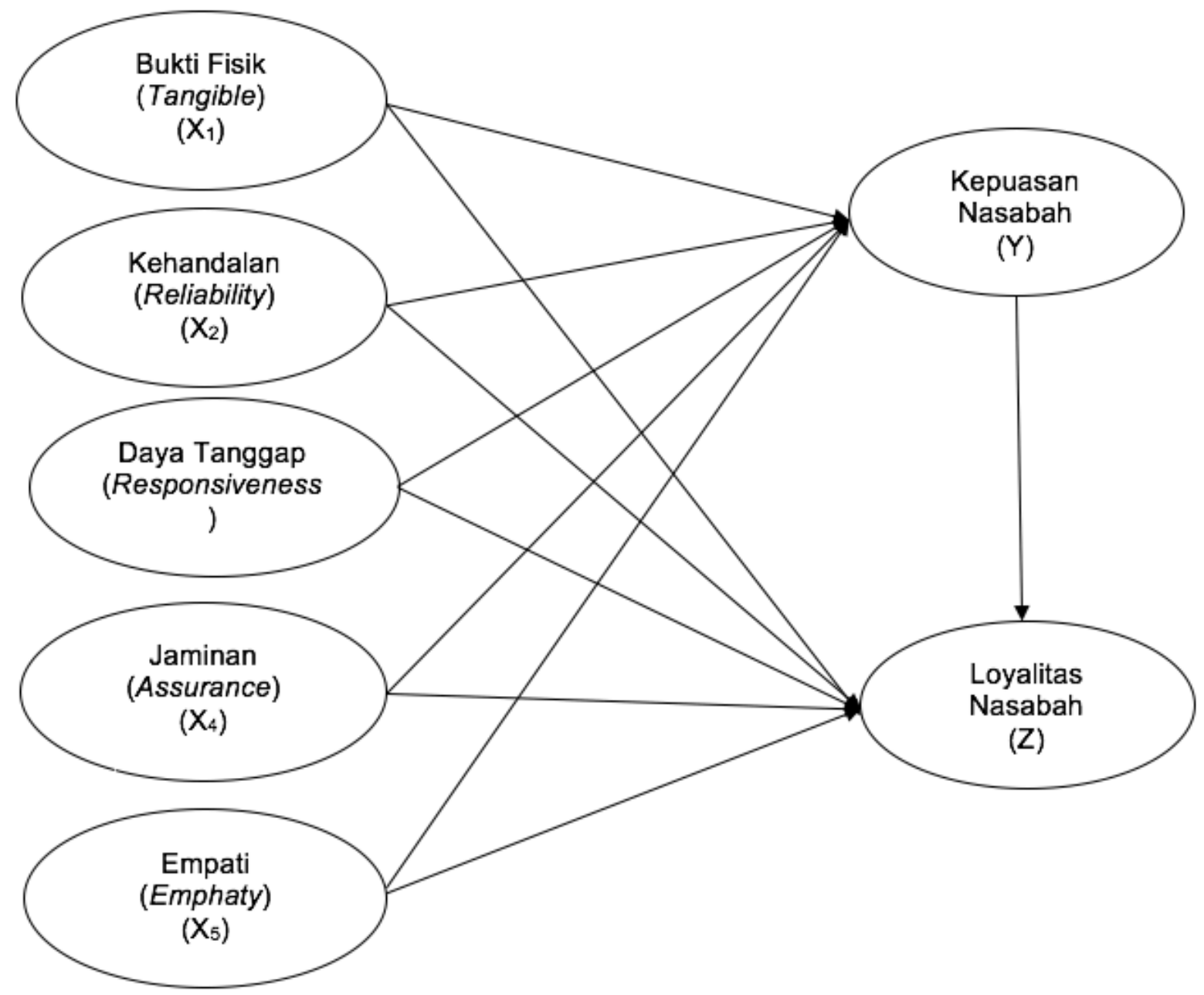

\section{Hipotesis}

1. Kualitas layanan (tangible) berpengaruh positif dan signifikan terhadap kepuasan nasabah.

2. Kualitas layanan (reliability) berpengaruh positif dan signifikan terhadap kepuasan nasabah.

3. Kualitas layanan (responsiveness) berpengaruh positif dan signifikan terhadap kepuasan nasabah.

4. Kualitas layanan (assurance) berpengaruh positif dan signifikan terhadap kepuasan nasabah.

5. Kualitas layanan (emphaty) berpengaruh positif dan signifikan terhadap kepuasan nasabah.

6. Kualitas layanan meliputi (tangible) berpengaruh positif dan signifikan terhadap loyalitas nasabah. 
7. Kualitas layanan meliputi (reliability) berpengaruh positif dan signifikan terhadap loyalitas nasabah.

8. Kualitas layanan meliputi (responsiveness) berpengaruh positif dan signifikan terhadap loyalitas nasabah.

9. Kualitas layanan meliputi (assurance) berpengaruh positif dan signifikan terhadap loyalitas nasabah.

10. Kualitas layanan meliputi (emphaty) berpengaruh positif dan signifikan terhadap loyalitas nasabah.

11. Kepuasan nasabah berpengaruh positif dan signifikan terhadap loyalitas nasabah.

12. Kualitas layanan meliputi (tangible) melalui kepuasan nasabah berpengaruh positif dan signifikan terhadap loyalitas nasabah.

13. Kualitas layanan meliputi (reliability) melalui kepuasan nasabah berpengaruh positif dan signifikan terhadap loyalitas nasabah.

14. Kualitas layanan meliputi (responsiveness) melalui kepuasan nasabah berpengaruh positif dan signifikan terhadap loyalitas nasabah.

15. Kualitas layanan (assurance) melalui kepuasan nasabah berpengaruh positif dan signifikan terhadap loyalitas nasabah.

16. Kualitas layanan meliputi (emphaty) melalui kepuasan nasabah berpengaruh positif dan signifikan terhadap loyalitas nasabah

\section{METODE PENELITIAN}

Pendekatan dalam penelitian ini menggunakan pendekatan kuantitatif, dimana dalam proses penelitian yang digunakan berdasarkan teori yang relevan dengan permasalahan yang diteliti untuk menemukan solusi dalam permasalahan tersebut. Pada penelitian ini menggunakan desain cross sectional study yaitu suatu penelitian yang bertujuan untuk melihat pengaruh pada waktu yang bersamaan. Penelitian ini dilakukan untuk mengetahui pengaruh variabel independen, kualitas layanan yaitu yang meliputi Kehandalan (Reability), Jaminan (Assurance), Bukti Fisik (Tangible), Empati (Empathy), Daya Tanggap (Responsiveness) terhadap variabel dependen yaitu kepuasan dan loyalitas nasabah pada PT Bank Negara Indonesia (Persero), Tbk Unit Siwa Kabupaten Wajo.

\section{Hipotesis}

a. Uji serempak (Uji F)

Uji F digunakan untuk mengetahui apakah seluruh variabel bebasnya secara bersama-sama mempunyai pengaruh yang bermakna terhadap variabel terikat. Pengujian dilakukan dengan membandingkan nilai $F_{\text {hitung }}$ dengan $F_{\text {tabel }}$ pada derajat kesalahan $5 \%(\alpha=0,05)$. Apabila nilai $F_{\text {hitung }}$ dari nilai $\mathrm{F}_{\text {tabel }}$ maka berarti variabel bebasnya secara serempak memberikan pengaruh yang bermakna terhadap variabel terikat. 
b. Uji Parsial (Uji T)

Uji T adalah untuk mengetahui apakah pengaruh masing-masing variabel terikat bermakna atau tidak. Pengujian dilakukan dengan membandingkan antara nilai thitung masing-masing variabel bebasnya memberikan pengaruh bermakna terhadap variabel terikat (Sugiyono, 2016).

\section{HASIL PENELITIAN DAN PEMBAHASAN}

\section{Hasil}

Dari hasil analisis dalam penelitian ini maka akan dilakukan uji mediasi dengan menggunakan sobel test dari masing-masing dimensi kualitas layanan (bukti fisik, kehandalan, daya tanggap, jaminan dan empati) terhadap loyalitas nasabah melalui kepuasan nasabah. Dimana dari hasil analsis dalam penelitian ini maka dapat diuraikan sebagai berikut :

1. Pengaruh bukti fisik (tangible) terhadap loyalitas nasabah melalui kepuasan nasabah pada PT Bank Negara Indonesia (Persero), Tbk Unit Siwa Kabupaten Wajo

Uji mediasi diawali dengan gambar uji mediasi bukti fisik (tangible) terhadap loyalitas nasabah melalui kepuasan nasabah pada PT Bank Negara Indonesia (Persero), Tbk Unit Siwa Kabupaten Wajo yang dapat disajikan sebagai berikut :

Gambar 1. Uji Mediasi Bukti Fisik (Tangible) terhadap Loyalitas Nasabah melalui Kepuasan Nasabah

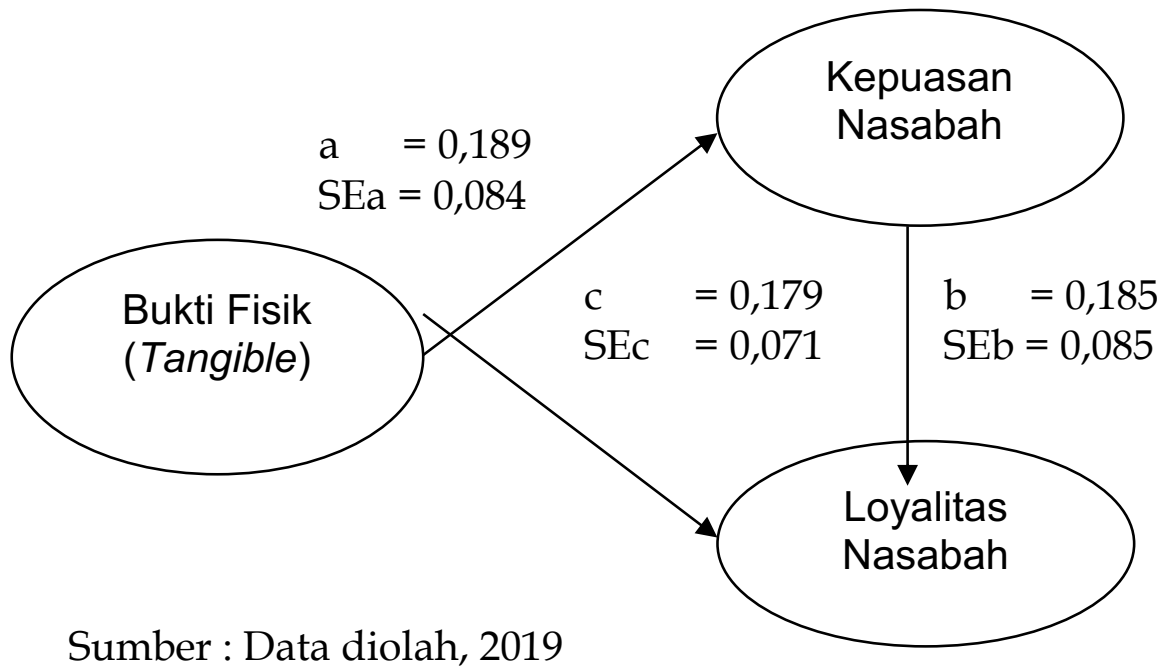

Berdasarkan gambar 1 maka besarnya pengaruh tidak langsung bukti fisik (tangible) terhadap loyalitas nasabah melalui kepuasan nasabah yaitu sebesar 0,034 atau 3,4\%. Sedangkan dalam menguji mediasi pengaruh bukti fisik terhadap loyalitas nasabah melalui kepuasan nasabah maka akan disajikan sobel test yang dapat dilihat melalui tabel berikut ini : 
Tabel 1. Hasil Uji Sobel Test Pengaruh Bukti Fisik (Tangible) terhadap Loyalitas Nasabah melalui Kepuasan Nasabah

\begin{tabular}{|c|c|c|c|c|}
\hline Input: & & Test statistic: & Std. Error: & $p$-value: \\
\hline a 0.189 & Sobel test: & 1.56434603 & 0.02235119 & 0.11773633 \\
\hline b 0.185 & Aroian test: & 1.49016037 & 0.02346392 & 0.13618207 \\
\hline$s_{a} 0.084$ & Goodman test: & 1.65084282 & 0.02118009 & 0.09877067 \\
\hline$s_{\mathrm{b}} 0.085$ & Reset all & & Calculate & \\
\hline
\end{tabular}

Sumber : Data diolah SPSS 21, 2020

Berdasarkan tabel 20 yakni hasil uji mediasi dengan sobel test maka diperoleh nilai sig. 0,117 > 0,05. Sehingga dapat dikatakan bahwa kepuasan nasabah tidak dapat memediasi bukti fisik (tangible) terhadap loyalitas nasabah.

2. Pengaruh kehandalan (reliability) terhadap loyalitas nasabah melalui kepuasan nasabah pada PT Bank Negara Indonesia (Persero), Tbk Unit Siwa Kabupaten Wajo

Berdasarkan hasil uji jalur terlebih dahulu maka sebelum dilakukan uji mediasi dengan sobel test maka akan disajikan gambar uji mediasi yang dapat disajikan melalui gambar 6 yaitu :

Gambar 2. Uji Mediasi Kehandalan (Reliability) terhadap Loyalitas Nasabah melalui Kepuasan Nasabah

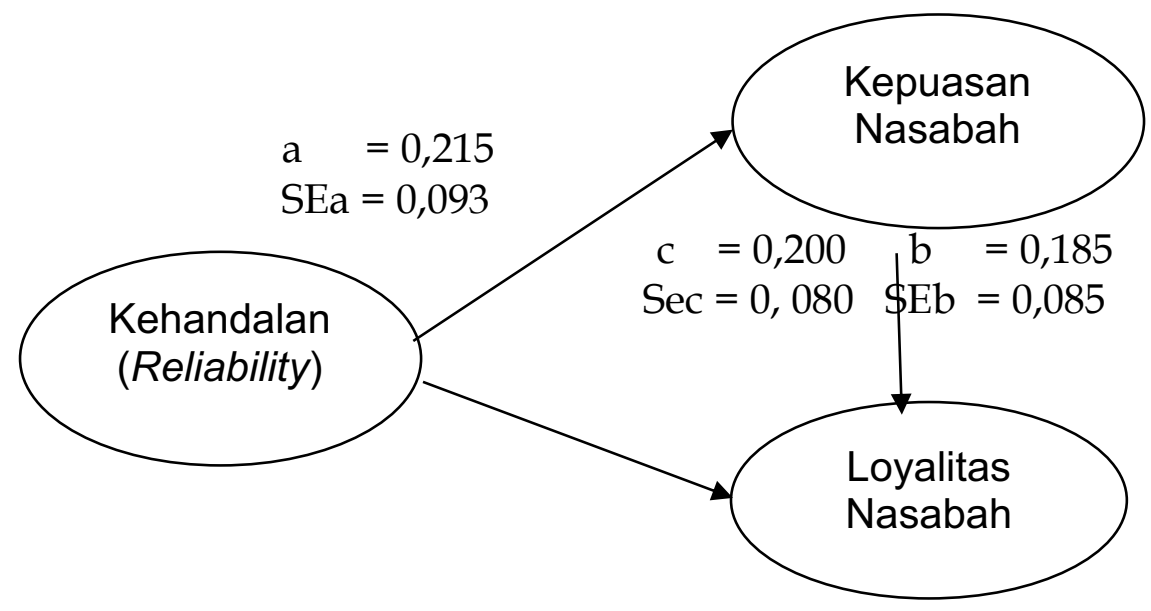

Sumber : Data diolah SPSS 21, 2020

Gambar 2 yakni hasil uji mediasi diperoleh besarnya pengaruh tidak langsung kehandalan (reliability) terhadap loyalitas nasabah melalui kepuasan nasabah yaitu sebesar 0,039 atau 3,9\%. Sedangkan dalam menguji mediasi pengaruh bukti fisik terhadap loyalitas nasabah melalui kepuasan nasabah maka akan disajikan sobel test yang dapat dilihat melalui tabel berikut ini : 
Tabel 2. Hasil Uji Sobel Test Pengaruh Kehandalan (Reliability) terhadap Loyalitas Nasabah melalui Kepuasan Nasabah

\begin{tabular}{|c|c|c|c|c|}
\hline Input: & & Test statistic: & Std. Error: & $p$-value: \\
\hline a 0.215 & Sobel test: & 1.58468946 & 0.02509955 & 0.11303691 \\
\hline b 0.185 & Aroian test: & 1.51149813 & 0.02631495 & 0.13066158 \\
\hline$s_{a} 0.093$ & Goodman test: & 1.669659 & 0.02382223 & 0.09498685 \\
\hline$s_{\mathrm{b}} 0.085$ & Reset all & & Calculate & \\
\hline
\end{tabular}

Sumber : Data diolah SPSS 21, 2020

Berdasarkan hasil uji sobel test pengaruh kehandalan (reliability) terhadap loyalitas nasabah melalui kepuasan nasabah diperoleh nilai sig. 0,113. Hal ini menunjukkan bahwa nilai sig. 0,113 >0,05, karena nilai 0,05. Berarti kepuasan nasabah tidak dapat memediasi pengaruh kehandalan (reliability) terhadap loyalitas nasabah pada PT Bank Negara Indonesia (Persero), Tbk Unit Siwa Kabupaten Wajo.

3. Pengaruh daya tanggap (responsiveness) terhadap loyalitas nasabah melalui kepuasan nasabah pada PT Bank Negara Indonesia (Persero), Tbk Unit Siwa Kabupaten Wajo

Sebelum dilkukan hasil uji sobel test, maka dapat disajikan gambar uji mediasi pengaruh daya tanggap (responsiveness) terhadap loyalitas nasabah melalui kepuasan nasabah yang dapat dilihat melalui gambar berikut ini :

Gambar 3. Uji Mediasi daya tanggap (responsiveness) terhadap Loyalitas Nasabah melalui Kepuasan Nasabah

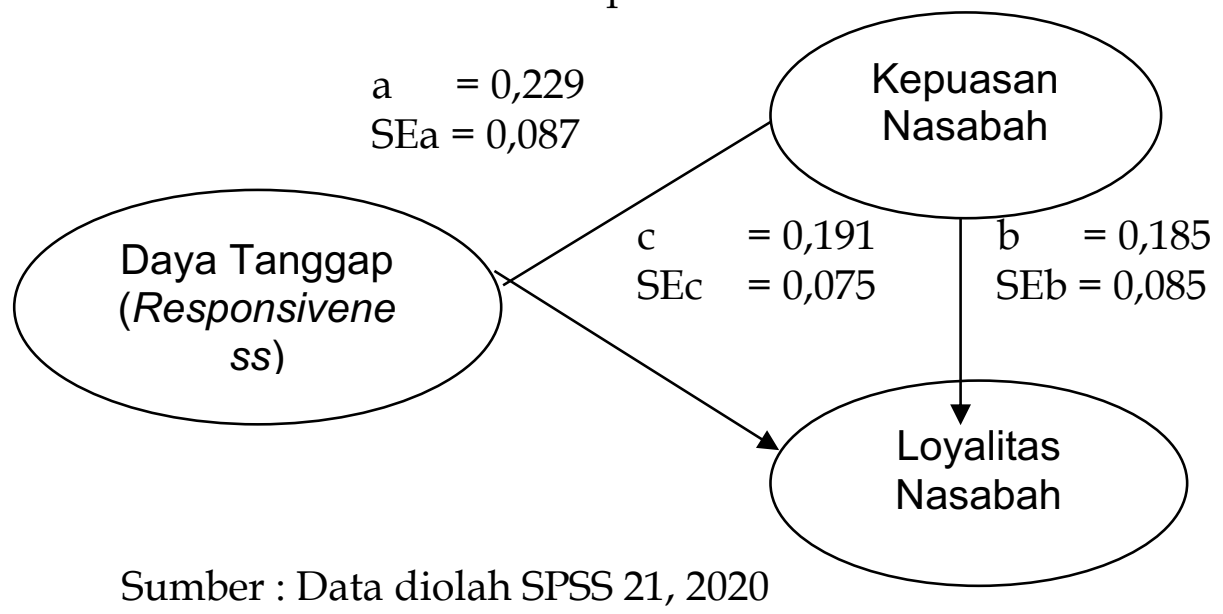

Berdasarkan gambar 7 maka besarnya pengaruh tidak langsung daya tanggap (responsiveness) terhadap loyalitas nasabah melalui kepuasan nasabah yaitu sebesar 0,042 atau $4,2 \%$. Selanjutnya akan disajikan hasil uji sobel test yang dapat disajikan melalui tabel berikut ini : 
Tabel 3. Hasil Uji Sobel Test Pengaruh Daya Tanggap (Responsiveness) terhadap Loyalitas Nasabah melalui Kepuasan Nasabah

\begin{tabular}{|c|c|c|c|c|}
\hline Input: & & Test statistic: & Std. Error: & $p$-value: \\
\hline a 0.229 & Sobel test: & 1.67733153 & 0.02525738 & 0.09347767 \\
\hline$b 0.185$ & Aroian test: & 1.6097532 & 0.0263177 & 0.10745175 \\
\hline$s_{a} 0.087$ & Goodman test: & 1.75420412 & 0.02415055 & 0.07939554 \\
\hline$s_{b} 0.085$ & Reset all & & Calculate & \\
\hline
\end{tabular}

Sumber :

Data diolah SPSS 21, 2020

Berdasarkan tabel 22 yakni hasil uji sobel test pengaruh daya tanggap (responsiveness) terhadap loyalitas nasabah melalui kepuasan nasabah diperoleh nilai sig. 0,093 > 0,05 . Hal ini dapat dikatakan kepuasan nasabah tidak dapat memediasi pengaruh daya tanggap (responsiveness) terhadap loyalitas nasabah pada PT Bank Negara Indonesia (Persero), Tbk Unit Siwa Kabupaten Wajo.

4. Pengaruh jaminan (assurance) terhadap loyalitas nasabah melalui kepuasan nasabah pada PT Bank Negara Indonesia (Persero), Tbk Unit Siwa Kabupaten Wajo

Sebelum dilakukan uji sobel test, maka terlebih dahulu akan disajikan gambar pengaruh jaminan (assurance) terhadap loyalitas nasabah melalui kepuasan nasabah pada PT Bank Negara Indonesia (Persero), Tbk Unit Siwa Kabupaten Wajo yang dapat dilihat melalui gambar berikut ini :

Gambaer 4. Uji Mediasi Jaminan (Assurance) terhadap Loyalitas Nasabah melalui Kepuasan Nasabah

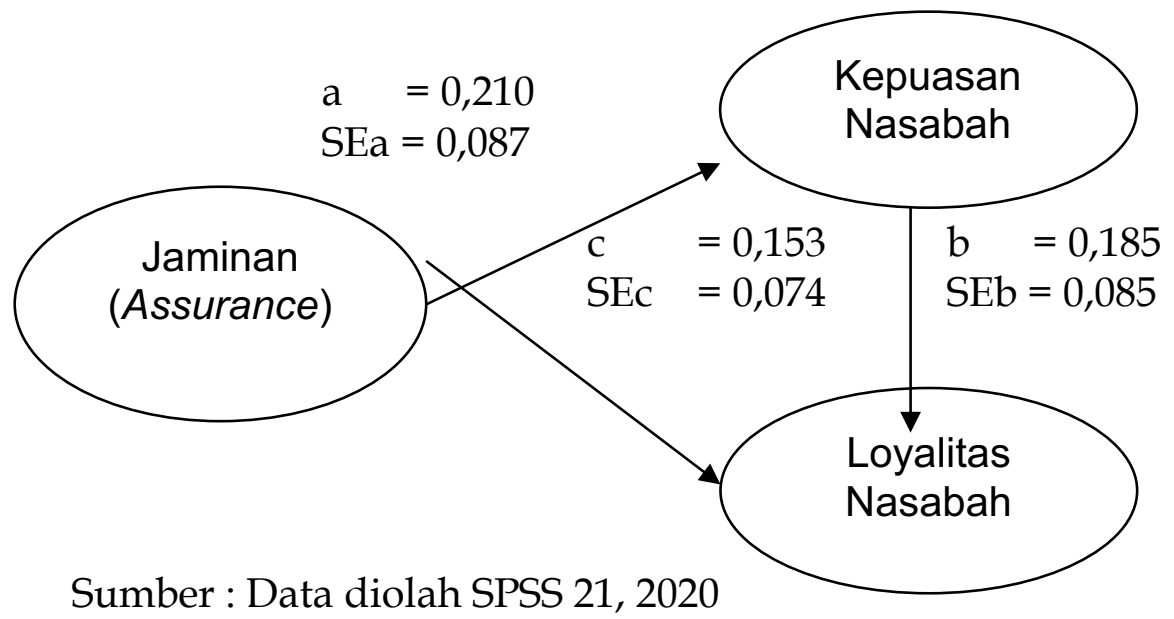

Berdasarkan gambar yakni hasil uji mediasi maka besarnya pengaruh tidak langsung jaminan (assurance) terhadap loyalitas nasabah melalui kepuasan nasabah yaitu sebesar 0,038 atau 3,8\%. Sehingga dapat disajikan kalkulasi sobel test yang dapat disajikan melalui tabel berikut ini : 
Tabel 4. Hasil Uji Sobel Test Pengaruh Jaminan (Assurance) terhadap Loyalitas Nasabah melalui Kepuasan Nasabah

\begin{tabular}{|c|c|c|c|c|}
\hline Input: & & Test statistic: & Std. Error: & $p$-value: \\
\hline a 0.210 & Sobel test: & 1.61640633 & 0.0240348 & 0.10600649 \\
\hline b 0.185 & Aroian test: & 1.54493307 & 0.02514672 & 0.12236245 \\
\hline$s_{a} 0.087$ & Goodman test: & 1.69881544 & 0.02286888 & 0.08935396 \\
\hline$s_{\mathrm{b}} 0.085$ & Reset all & & Calculate & \\
\hline
\end{tabular}

Sumber :

Data diolah SPSS 21, 2020

Berdasarkan tabel 23 yakni uji sobel test maka diperoleh nilai sig. 0,106 > 0,05, hal ini dapat disimpulkan bahwa kepuasan nasabah tidak dapat memediasi jaminan (assurance) terhadap loyalitas nasabah pada PT Bank Negara Indonesia (Persero), Tbk Unit Siwa Kabupaten Wajo.

5. Pengaruh empati (emphaty) terhadap loyalitas nasabah melalui kepuasan nasabah pada PT Bank Negara Indonesia (Persero), Tbk Unit Siwa Kabupaten Wajo

Sebelum dilakukan hasil mediasi pengaruh empati terhadap loyalitas nasabah melalui kepuasan nasabah, maka dapat disajikan gambar hasil uji mediasi yang dapat disajikan sebagai berikut :

Gambar 5. Uji Mediasi Empati (Emphaty) terhadap Loyalitas Nasabah melalui Kepuasan Nasabah

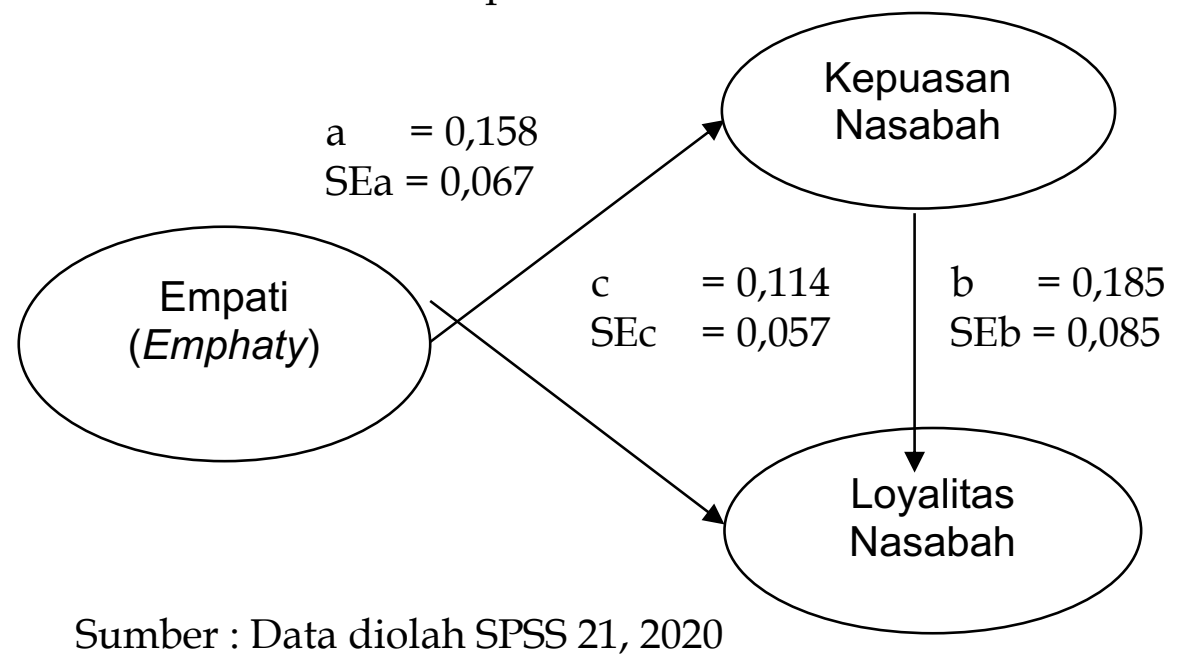

Berdasarkan gambar 5 maka besarnya pengaruh tidak langsung empati (emphaty) terhadap loyalitas nasabah melalui kepuasan nasabah yaitu sebesar 0,029 atau 2,9\%. Selanjutnya akan disajikan hasil uji sobel test dalam uji mediasi yang dapat disajikan pada tabel berikut ini : 
Tabel 5. Hasil Uji Sobel Test Pengaruh Empati (Emphaty) terhadap Loyalitas Nasabah melalui Kepuasan Nasabah

\begin{tabular}{|c|c|c|c|c|}
\hline Input: & & Test statistic: & Std. Error: & $p$-value: \\
\hline a 0.158 & Sobel test: & 1.59939223 & 0.01827569 & 0.10973348 \\
\hline$b 0.185$ & Aroian test: & 1.52697161 & 0.01914246 & 0.12676807 \\
\hline$s_{a} 0.067$ & Goodman test: & 1.68320208 & 0.01736571 & 0.09233598 \\
\hline$s_{\mathrm{b}} 0.085$ & Reset all & & Calculate & \\
\hline
\end{tabular}

Sumber : Data diolah SPSS 21, 2020

Berdasarkan hasil uji sobel test yakni pengaruh empati (emphaty) terhadap loyalitas nasabah melalui kepuasan nasabah pada PT Bank Negara Indonesia (Persero), Tbk Unit Siwa Kabupaten Wajo diiperoleh nilai sig. 0,109 > 0,05. Hal ini dikatakan bahwa kepuasan nasabah tidak dapat memediasi pengaruh empati (emphaty) terhadap loyalitas nasabah pada PT Bank Negara Indonesia (Persero), Tbk Unit Siwa Kabupaten Wajo.

\section{Pembahasan}

Pembahasan hasil penelitian dilakukan menguji pengaruh dimensi pelayanan (bukti fisik, kehandalan, daya tanggap, jaminan dan empati) terhadap kepuasan nasabah dan loyalitas nasabah pada PT Bank Negara Indonesia (Persero), Tbk Unit Siwa Kabupaten Wajo. Dimana dalam melakukan pengamatan terlihat bahwa dimensi pelayanan berpengaruh terhadap kepuasan dan loyalitas nasabah. Sedangkan uji mediasi dengan menggunakan sobel test terlihat bahwa kepuasan nasabah tidak dapat memediasi pengaruh kualitas pelayanan terhadap loyalitas nasabah.

Adapun pembahasan hasil penelitian ini yang dapat diuraikan yaitu sebagai berikut :

1. Pengaruh dimensi kualitas pelayanan (bukti fisik, kehandalan, daya tanggap, jaminan dan empati) terhadap kepuasan nasabah

Berdasarkan hasil analisis data dalam penelitian ini yang menunjukkan dimensi kualitas pelayanan berpengaruh positif terhadap kepuasan nasabah pada PT Bank Negara Indonesia (Persero), Tbk Unit Siwa Kabupaten Wajo. Hal ini dapat diartikan kualitas pelayanan yang meliputi bukti fisik, kehandalan, daya tanggap, jaminan dan empati dapat meningkatkan kepuasan nasabah.

Kemudian dari hasil uji parsial yang telah dilakukan yang menunjukkan bahwa kualitas pelayanan yang terdiri dari bukti fisik, kehandalan, daya tanggap, jaminan dan empati memberikan pengaruh nyata dalam meningkatkan kepuasan nasabah. Dimana semakin baik pemberian kualitas pelayanan yang meliputi bukti fisik, kehandalan, daya tanggap, jaminan dan empati maka akan dapat memberikan pengaruh yang berarti/nyata dalam meningkatkan kepuasan nasabah pada PT Bank Negara Indonesia (Persero), Tbk Unit Siwa Kabupaten Wajo. 
Penelitian yang sebagaimana dilakukan oleh Pawestriningsih (2016) dengan judul penelitian "Pengaruh kualitas Pelayanan Jasa Terhadap Kepuasan Nasabah (Survei Pada Nasabah Perum Pegadaian Kantor Cabang Syariah Tlogomas Malang)" yang menemukan bahwa kualitas pelayanan yang terdiri dari bukti fisik (tangible), kehandalan (reliability), daya tanggap (responsiveness), jaminan (assurance), empati (emphaty) berpengaruh signifikan terhadap kepuasan nasabah, sedangkan penelitian yang dilakukan oleh Montolalu (2015) dengan judul penelitian "Pengaruh Kualitas Layanan Promosi dan Kepuasan Terhadap Loyalitas Nasabah Pada PT. Pegadaian Cabang Manado Timur" yang menemukan bahwa kualitas layanan, promosi dan kepuasan berpengaruh signifikan positif terhadap loyalitas nasabah. Selanjutnya penelitian yang dilakukan oleh (Wahab, 2017) dengan judul penelitian "Pengaruh Kualitas Pelayanan Terhadap Kepuasan Nasabah Pegadaian Syariah di Kota Pekanbaru" menemukan bahwa variabel bukti fisik (tangible) dan kehandalan (reliability) tidak berpengaruh terhadap kepuasan nasabah sedangkan variabel daya tanggap (responsiveness), jaminan (assurance) dan empati (emphaty) berpengaruh terhadap kepuasan nasabah. Sehingga dalam penelitian ini sesuai dengan yang dilakukan oleh Pawestriningsih (2016), Montolalu (2015), namun penelitian yang dilakukan oleh (Wahab, 2017) tidak sesuai dengan penelitian ini.

2. Pengaruh dimensi kualitas pelayanan (bukti fisik, kehandalan, daya tanggap, jaminan dan empati) terhadap loyalitas nasabah

Hasil penelitian menunjukkan bahwa kualitas pelayanan melalui bukti fisik (tangible), kehandalan (reliability), daya tanggap (responsiveness), jaminan (assurance) dan empati (emphaty) berpengaruh positif terhadap loyalitas nasabah. Hal ini dapat dikatakan bahwa kualitas pelayanan bukti fisik (tangible), kehandalan (reliability), daya tanggap (responsiveness), jaminan (assurance) dan empati (emphaty) berpengaruh positif terhadap peningkatan loyalitas nasabah. Hal ini dapat diartikan bahwa kualitas pelayanan bukti fisik, kehandalan, daya tanggap, jaminan dan empati dapat meningkatkan loyalitas nasabah pada PT Bank Negara Indonesia (Persero), Tbk Unit Siwa Kabupaten Wajo.

Kemudian secara empirik yang menunjukkan bahwa kualitas pelayanan maliputi bukti fisik, kehandalan, daya tanggap, jaminan dan empati memberikan pengaruh yang nyata dalam maningkatkan loyalitas nasabah pada PT Bank Negara Indonesia (Persero), Tbk Unit Siwa Kabupaten Wajo. Dimana kualitas pelayanan dapat memberikan pengaruh yang berarti dalam meningkatkan loyalitas nasabah.

Penelitian yang dilakukan oleh (Nugroho, 2015) dengan judul penelitian "Pengaruh Kualitas Pelayanan Terhadap Kepuasan dan Loyalitas Pelanggan (Survei pada Pelanggan Speedy Telkom di Kota Surakarta)" yang menemukan bahwa kualitas pelayanan berpengaruh secara signifikan terhadap kepuasan pelanggan dan kualitas pelayanan berpengaruh secara signifikan terhadap loyalitas pelanggan. Dengan demikian dalam penelitian ini sesuai dengan penelitian yang dilakukan oleh (Nugroho, 2015). 
3. Pengaruh kepuasan nasabah terhadap loyalitas nasabah

Berdasarkan hasil analisis mengenai pengaruh kepuasan nasabah terhadap loyalitas nasabah. Dimana dalam penelitian ini diperoleh temuan bahwa kepuasan nasabah berpengaruh positif terhadap loyalitas nasabah, yang artinya kepuasan nasabah dapat meningkatkan loyalitas nasabah pada PT Bank Negara Indonesia (Persero), Tbk Unit Siwa Kabupaten Wajo.

Kemudian secara empirik diperoleh temuan bahwa kepuasan nasabah berpengaruh secara signifikan terhadap loyalitas nasabah. Dengan kata lain bahwa kepuasan nasabah memberikan pengaruh yang nyata dalam meningkatkan loyalitas nasabah pada PT Bank Negara Indonesia (Persero), Tbk Unit Siwa Kabupaten Wajo.

Penelitian (Nuchasara, et.al, 2015) dengan judul penelitian "Pengaruh Kualitas Pelayanan, Kepuasan Pelanggan dan Loyalitas Pelanggan Pada Perusahaan Audit Thailand menemukan hasil kualitas layanan berpengaruh positif dan signifikan terhadap kepuasan dan loyalitas pelanggan, kualitas layanan berpengaruh positif terhadap loyalitas pelanggan dan kepuasan pelanggan berpengaruh positif terhadap loyalitas pelanggan. Sehingga dalam penelitian ini sesuai dengan penelitian yang dilakukan oleh (Nuchasara, et.al, 2015).

4. Pengaruh dimensi kualitas pelayanan (bukti fisik, kehandalan, daya tanggap, jaminan dan empati) terhadap loyalitas nasabah dimediasi oleh kepuasan nasabah

Berdasarkan hasil analisis yang telah dilakukan yaitu dalam uji mediasi dengan menggunakan sobel test. Dimana dari hasil analisis yang telah dilakukan selama ini terlihat bahwa kepuasan nasabah tidak dapat memediasi pengaruh kualitas pelayanan (bukti fisik, kehandalan, daya tanggap, jaminan, dan empati) terhadap loyalitas nasabah. Namun kelima dimensi kualitas pelayanan hanya dapat berpengaruh langsung terhadap loyalitas nasabah.

Penelitian yang dilakukan oleh (Rofiah dan Wahyuni, 2017) dengan judul penelitian "Kualitas Pelayanan dan Pengaruhnya Terhadap Loyalitas Pelanggan yang Di Mediasi Oleh Kepuasan Di Bank Muamalat Jombang" menemukan bahwa kualitas pelayanan berpengaruh signifikan terhadap kepuasan, kualitas pelayanan dan kepuasan pelanggan berpengaruh signifikan terhadap loyalitas pelanggan dan variabel kepuasan berpengaruh signifikan terhadap loyalitas pelanggan , sedangkan penelitian yang dilakukan oleh (Hermawan, et.al, 2017) dengan judul penelitian "Pengaruh kualitas Layanan dan Persepsi Harga Terhadap Citra Perusahaan, Kepuasan Pelanggan serta Loyalitas Pelanggan Pada Perusahaan Penyedia Layanan Telekomunikasi Seluler yang menemukan bahwa kualitas layanan secara berpengaruh positif dan signifikan terhadap terhadap pelanggan melalui mediasi kepuasan pelanggan. Sehingga dalam penelitian ini sesuai dengan penelitian yang dilakukan oleh (Rofiah dan Wahyuni, 2017)dan penelitian yang dilakukan oleh (Hermawan, et.al, 2017) tidak sesuai dengan penelitian ini. 


\section{KESIMPULAN}

Berdasarkan hasil analisis dan pembahasan yang telah diuraikan sebelumnya, maka selanjutnya akan disajikan beberapa kesimpulan yaitu sebagai berikut :

1. Pengaruh kualitas layanan melalui bukti fisik (tangible), kehandalan (reliability), daya tanggap (resvonsiveness), jaminan (assurance) dan empati (emphaty) berpengaruh positif dan signifikan terhadap kepuasan nasabah pada PT Bank Negara Indonesia (Persero), Tbk Unit Siwa Kabupaten Wajo.

2. Pengaruh kualitas layanan melalui bukti fisik (tangible), kehandalan (reliability), daya tanggap (resvonsiveness), jaminan (assurance) dan empati (emphaty) berpengaruh positif dan signifikan terhadap loyalitas nasabah pada PT Bank Negara Indonesia (Persero), Tbk Unit Siwa Kabupaten Wajo.

3. Pengaruh kepuasan nasabah terhadap loyalitas nasabah pada PT Bank Negara Indonesia (Persero), Tbk Unit Siwa Kabupaten Wajo berpengaruh positif dan signifikan.

4. Hasil uji mediasi yang menunjukkan bahwa kualitas pelayanan bukti fisik (tangible), kehandalan (reliability), daya tanggap (responsiveness), jaminan (assurance) dan empati (emphaty) berpengaruh positif dan tidak signifikan terhadap loyalitas melalui kepuasan nasabah. Artinya bahwa pihak bank telah memberikan pelayanan yang optimal namun masih adanya nasabah yang kurang puas terhadap waktu tunggu antrian yang mereka anggap masih cukup lama sehingga menyebabkan masih adanya nasabah yang kurang puas terhadap pelayanan yang diberikan oleh pihak PT Bank Negara Indonesia (Persero), Tbk Unit Siwa Kabupaten Wajo.

\section{DAFTAR PUSTAKA}

Assauri, S. (2018). Manajemen Bisnis Pemasaran. Cetakan Kesatu, Penerbit : Rajagrafindo Persada, Depok.

Dewi, K.R.P.U.G, Yasa, N.K.Y. dan Sukaatmadja. P.G. 2014. Pengaruh Kualitas Pelayanan Terhadap Kepuasan dan Loyalitas Nasabah PT BPR Hoki Di Kabupaten Tabanan. E-Jurnal Ekonomi dan Bisnis Universitas Udayana.

Dimyati, Mohamad. 2018. Pendekatan Hayati : Strategi Pemasaran Untuk Menghadapi Persaingan Yang Dinamis, The Hayati Approach : A Marketing Strategy For Dynamic Competition. Penerbit : Mitra Wacana Media, Jakarta.

Herlambang, S (2014). Basic Marketing (Dasar - Dasar Pemasaran) Cara Mudah Memahami Ilmu Pemasaran. Cetakan Pertama, Penerbit : Gosyen Publishing, Yogyakarta.

Hermawan, B. asalamah, S. Djamereng, A. \& Plyriadi, A. (2017). IRA-International Journal of Management \& Social Sciences ISSN 2455-2267; Vol.08, Issue 01 (July 2017) Pg. no. 62-73 Institute of Research Advances. Universitas Muslim Indonesia.

Kotler, P dan Keller. K.L. (2016). Marketing Management 16 edition. New Jersey: Pearson. 
Nardiman, Y. (2014). Pengaruh Harga, Promosi dan Kualitas Pelayanan Terhadap Kepuasan dan Dampaknya Pada Loyalitas Nasabah Adira Finance di Kecamatan Kinali Kabupaten Pasaman Barat. Jurnal

Nuchasara, P, Fadzil, F. Ismail, S.S.S. (2015). Service Quality, Customer Satisfaction And Customer Loyalty In Thailand's Audit Firms. International Journal of Management and Applied Science, ISSN: 2394-7926 Volume-1, Issue-5, June2015.

Nugroho, N.T. (2015). Jurnal Tesis “ Pengaruh Kualitas Pelayanan Terhadap Kepuasan dan Loyalitas Pelanggan (Survey Pada Pelanggan Speedy Telkom Di Surakarta)". Surakarta.

Rofiah, C dan Wahyuni, D. (2017). Jurnal Tesis. “ Pengaruh Kualitas Pelayanan Dan Pengaruhnya Terhadap Loyalitas Pelanggan Yang Di Mediasi Oleh Kepuasan Di Bank Muamalat Jombang". Jombang

Sigit, N.C. dan Soliha. E. (2017). Kualitas Produk Dan Kualitas Layanan Terhadap Kepuasan Dan Loyalitas Nasabah. Jurnal Keuangan Perbankan, 21 (1): 157-168

Sugiyono, (2016). Statistik Untuk Penelitian. Cetakan Kedua Puluh Tujuh, Penerbit : Alfabeta, Bandung.

Tjiptono, F. (2014). Pemasaran Jasa, Edisi Kedua, Cetakan Ketujuh, Penerbit : Andi Offset, Yogyakarta.

Tjiptono, F dan Chandra. G. (2016). Service Quality Dan Satisfaction. Edisi Keempat. Penerbit: Andi, Yogyakarta.

Wahab, W. (2017). Jurnal Tesis. "Pengaruh Kualitas Pelayanan Terhadap Kepuasan Nasabah Pegadaian Syariah Kota Pekan Baru". Pekanbaru.

Wijayanto, K. (2015). Pengaruh Kualitas Pelayanan Terhadap Kepuasan Dan Loyalitas Nasabah Bank. Jurnal Ekonomi Manajemen Sumber Daya Vol. 17 No. 1.

Yaqin, A. dan Ilfitriah, A.M. (2014). Pengaruh Kualitas Pelayanan Terhadap Kepuasan Dan Loyalitas Nasabah Bank Pengguna E-Banking Di Surabaya. Journal Of Business And Banking Vol. 4 No. 2. 